\title{
Acyrtus pauciradiatus, a new species of clingfish (Teleostei: Gobiesocidae) from Fernando de Noronha Archipelago, Pernambuco state, Northeastern Brazil
}

\author{
Cláudio L. S. Sampaio*, José de Anchieta C. C. Nunes** \\ and Liana F. Mendes***
}

Acyrtus pauciradiatus, new species, is described on the basis of three specimens collected at Fernando de Noronha Archipelago, state of Pernambuco, Brazil. It differs from its congeners by having a reduced number of rays in the pectoral, dorsal, and anal fins and is more isolated geographically, than any other species in the genus.

Acyrtus pauciradiatus, espécie nova, é descrita com base em três espécimes coletados no arquipélago de Fernando de Noronha, Pernambuco, Brasil. Ela difere dos seus congêneres por possuir número reduzido de raios das nadadeiras dorsal, peitoral e anal e apresenta o maior isolamento geográfico em relação as demais espécies do gênero.

Key words: Oceanic island, endemism, reef fish, systematics.

\section{Introduction}

Clingfishes (Gobiesocidae) are small, flattened and usually cryptic fishes that are most common on hard substrates in the shallow wave-washed areas immediately below the low tide mark (Thresher, 1984). All clingfishes are characterized mainly by the modified pelvic fins that form a disc, used to adhere to the substrate and by the presence of one small spine and four (rarely five) soft rays in the pelvic fin. Also, clingfishes have a spineless dorsal fin, head and body scaleless, genital papilla behind the anus, and no swim bladder (Nelson, 1994).

The family Gobiesocidae includes 43 genera and about 150 species (Hutchins, 2003) distributed in shallow waters along tropical and temperate seashores.

Briggs (1955) reviewed the western Atlantic clingfishes and recognized nine species distributed in five genera. His genera were diagnosed based on having a single or double pelvic disc, three or three and half gill arches, and gill membranes free or attached to isthmus. Twenty-five species of clingfishes occur in the Western Atlantic (Williams \& Tyler, 2003), excluding the new species described here and according to Menezes (2003) five species and three genera of clingfishes are found in Brazilian waters.

Fernando de Noronha Archipelago lies at $03^{\circ} 50^{\prime} \mathrm{S}$ $32^{\circ} 25^{\prime} \mathrm{W}$, about $340 \mathrm{~km}$ northeast off Brazil mainland coast. This archipelago's 20 islands are characterized by clear waters, low coral diversity and are influenced by the warm South Equatorial Current and Atlantic Equatorial Current (Eston et al., 1986; Nunan, 1992; Rocha, 2003).

Recent collections taken from coastal waters of the Archipelago (Mendes, 2000) included three specimens of a clingfish that belongs to the gobiesocid genus Acyrtus Schultz, 1944, based on its having a broad central portion of the upper lip.

Relatively little is known about members of the genus Acyrtus, probably due to the cryptic habit of the species included, together with their small size and relatively low abundance. Herein, we describe a new species of Acyrtus from the Fernando de Noronha Archipelago, off northeastern Brazil.

\footnotetext{
*Programa de Pós-graduação em Zoologia, Universidade Federal da Paraíba, Departamento de Sistemática e Ecologia, CCEN. 58.059-900 João Pessoa, PB, Brazil. e-mail: clssampaio@ig.com.br

**Universidade Católica do Salvador, Instituto de Ciências Biológicas. Salvador, Bahia, Brazil. e-mail: sotaliaba@bol.com.br

*** Universidade Federal do Rio Grande do Norte, Departamento de Botânica, Ecologia e Zoologia. Natal, Rio Grande do Norte, Brazil. email: liana_oceanica@yahoo.com.br
} 


\section{Material and Methods}

The three specimens of clingfishes were captured using formalin (10\%) and plastic bags during SCUBA dives in Ressurreta Bay, at Rata Island, Fernando de Noronha archipelago in 1997 (see Maida \& Ferreira, 1997 for map and area description). This bay is characterized by calm waters, with maximum depth of 12 meters. The substrate is composed of rocks and incrusting fauna and flora. Calcareous and Pheophyta algae, sponges, and ascidians are very common in the reefs concavities (Mendes, 2000).

The method used for making measurements and counts (morphometrics and meristics) and the description follow Briggs (1955). Measurements were made using a $0.1 \mathrm{~mm}$ precision caliper.

Type specimens of the new species were deposited in the ichthyological collections of the Museu de Zoologia da Universidade de São Paulo (MZUSP), Centro de Ciências Biológicas da Universidade Federal do Rio Grande do Norte (UFRN) and Museu Oceanográfico do Vale do Itajaí (MOVI).

\section{Acyrtus pauciradiatus, new species}

Fig. 1

Holotype. MZUSP 84516, $16.3 \mathrm{~mm}$ SL, Brazil, off State of Pernambuco, Fernando de Noronha Archipelago, Rata Island, in Ressurreta Bay, at a depth of 12m; L. F. Mendes, 12 Dec 1997.

Paratypes. UFRN 0001, 13.2 mm SL; MOVI 37363, 12.6 mm SL, collected with holotype.

Diagnosis. Acyrtus pauciradiatus can be readily distinguished from all its congeners by the following combination of characters: pelvic disc small (2.9-3.7 times in SL vs. 2.8-3.2 in Acyrtus rubiginosus, and 2.3-2.6 in Acyrtus artius), shallow body depth (5.4-6.6 times in SL vs. 4.9-5.4 in A. rubiginosus, and 4.2-4.3 in A. artius), broad interorbital width (2.2-2.5 times in head length $v s .3 .0-3.8$ in $A$. rubiginosus, and 2.8-3.6 in A. artius), broad peduncle depth (0.5-0.7 times in its length vs. 1.3-2.3 in A. rubiginosus, and 1.2-1.4 in A. artius), short snout (6.6-11.0 times in head length vs. 3.3-4.3 in Acyrtus rubiginosus, and 3.7-4.0 in A. artius), short post-dorsal length (1.1-1.5 times in dorsal length vs. 0.8-1.0 in A. rubiginosus, and 1.0-1.2 in A. artius), dorsal-fin rays 7-8 (vs. 9-10 in A. rubiginosus, and 8 - 9 in A. artius), anal-fin rays $6-8$ (vs. 7-9 in A. rubiginosus, and 7 in A. artius), caudal-fin rays 11-12 (vs. 7-9 in A. rubiginosus, and 8 - 9 in A. artius) and pectoral-fin rays 20-22 (vs. 25-26 in A. rubiginosus, and 24- 25 in A. artius). Furthermore, the new species can be diagnosed by ten rows of papillae across width of disc region $\mathrm{A}$; ten rows across width of disc in region $\mathrm{B}$, and four or five rows across width of disc in region $\mathrm{C}$.
Description: Meristic and proportional measurements of the holotype and two paratypes given in Table 1. Body moderately depressed, depth 5.4-6.6 in SL. Caudal peduncle short 0.5-0.7 in its length. Head depressed, head width 2.5-2.6 in SL. Snout steep with a rounded outline, 6.6-11.0 in head length, lower lip mostly covered with small papillae. Diameter of eye 0.6-0.8 in interorbital space and 3.0-4.2 in head length. Disc suction large, 2.9-3.7 in SL. Posterior nostril in front of anterior edge of eye, anterior nostril with an intermediate, branched dermal flap extending from is posterior margin. Dorsal to caudal distance great, 1.1-1.5 in dorsal fin length. Anus closer to anal origin than to rear margin of disc. Skin granular, covered with small glands. Maximum known size $16.3 \mathrm{~mm}$ SL.

Color in alcohol. Ground color uniform pale and colorless in the type series. Fins hyaline. Very diminutive chromatophores, associated with small gland (visible only with stereomicroscope) on dorsal and lateral surfaces of body.

Color in life. L. F. Mendes made observations of pigmentation in live specimens at the time of collection. Body uniformly pale reddish pink, without marks or bands. The color of the type specimens contrasts with the color of the patch of brown algae (Sargassum sp. and Dictyota sp. Division Phaeophyta), and the living colonies of coral Montastrea cavernosa (predominant coral in Noronha), surrounding the hole from which it was collected.

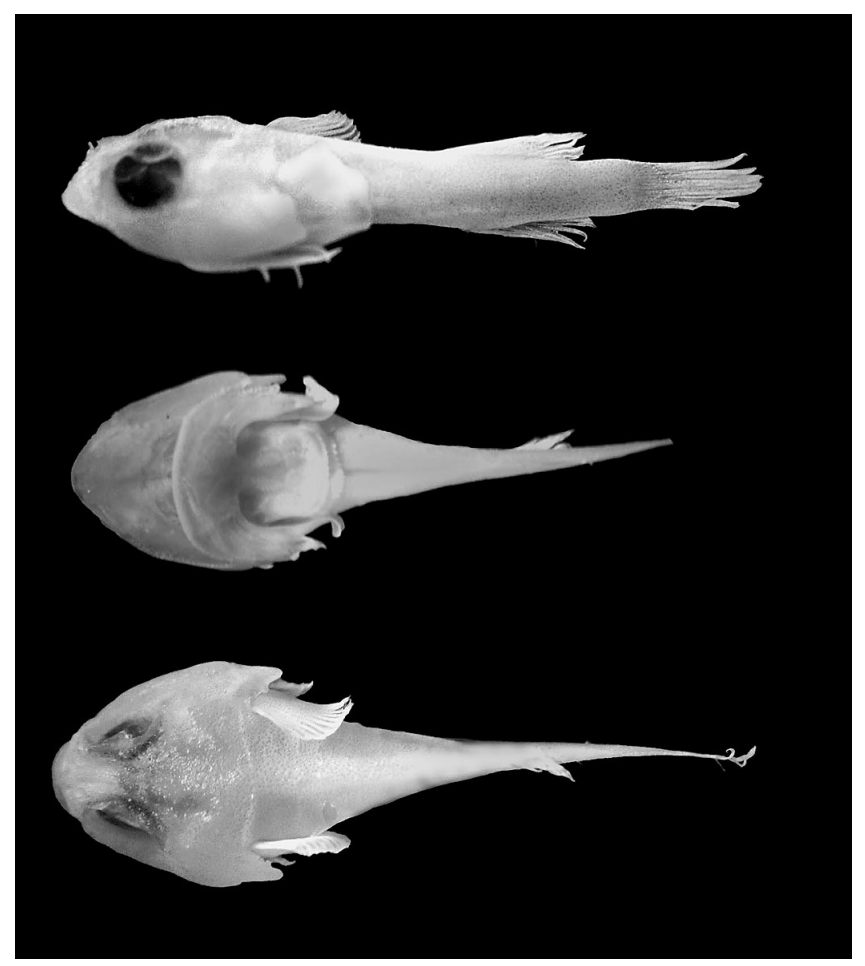

Fig. 1. Acyrtus pauciradiatus, new species. Holotype. MZUSP 84516, $16.3 \mathrm{~mm}$ SL, Brazil, off State of Pernambuco, Fernando de Noronha Archipelago, Rata Island, in Ressurreta Bay. 
Table 1. Morphometric and meristic characters for the holotype and paratypes of Acyrtus pauciradiatus.

\begin{tabular}{lccc}
\hline & $\begin{array}{c}\text { Holotype } \\
\text { MZUSP }\end{array}$ & $\begin{array}{c}\text { Paratype } \\
\text { UFRN }\end{array}$ & $\begin{array}{c}\text { Paratype } \\
\text { MOVI }\end{array}$ \\
Collection number & 84516 & 0001 & 37363 \\
Standard length (mm) & 16.3 & 13.2 & 12.6 \\
Total length & 20.1 & 17.4 & 15.7 \\
Head length & 6.6 & 5.6 & 5.5 \\
Head width & 6.3 & 5.3 & 4.8 \\
Head depth & 3 & 2.7 & 2.4 \\
Interorbital width & 2.8 & 2.5 & 2.2 \\
Cornea diameter & 2.2 & 1.5 & 1.3 \\
Disc length & 5.6 & 4.1 & 3.4 \\
Disc width & 5.9 & 4.5 & 4 \\
Snout length & 1 & 0.7 & 0.5 \\
Pre-dorsal distance & 11.4 & 9.4 & 8.5 \\
Caudal peduncle depth & 1.8 & 1.5 & 1.2 \\
Caudal peduncle length & 1.3 & 0.8 & 0.6 \\
Anus to posterior margin of disc & 2 & 1.7 & 1.5 \\
Anus to anal fin origin & 1.5 & 1.2 & 0.7 \\
Pre-anal distance & 11.3 & 10 & 9.1 \\
Pectoral length & 3 & 2.5 & 2.2 \\
Dorsal length & 3 & 2 & 2 \\
Post-dorsal - caudal & 2 & 1.7 & 1.5 \\
Body depth & 3 & 2 & 2 \\
\hline
\end{tabular}

Distribution. Known only in shallow water at Fernando de Noronha Archipelago, off northeastern Brazil. Probably endemic to the Noronha hotspot, which includes the Fernando de Noronha Archipelago and Atol das Rocas (Rocha, 2003).

Habitat notes. The new species is found in shallow waters at the Fernando de Noronha Archipelago, occurring on hardbottom habitats that consist of areas rich in calcareous and brown algae, corals and sponges. Acyrtus pauciradiatus was collected with the yellownose goby, Elacatinus sp.2 (sensu Moura et al., 2003); manyscaled blenny, Starksia multilepis Williams \& Mounts, 2003 and brownbar Goby, Priolepis dawsoni Greenfield, 1989, all endemic cryptic species from Brazilian reefs. Acyrtus pauciradiatus apparently is uncommon at the Noronha Archipelago and only three specimens have been collected.

Etymology. The new species is named pauciradiatus (Latin: having few rays) with reference to the dorsal, anal and pectoral fins rays, which have fewer rays than the other members of genus. The common name "Noronha's Clingfish" is suggested.

\section{Discussion}

The distribution of the genus Acyrtus Schultz 1944 includes only the Western Atlantic (Briggs, 1955; Böhlke \& Chaplin, 1993; Smith, 1997).

Acyrtus species have not been previously reported from any oceanic island off northeastern Brazil (Lubbock \& Edwards, 1981; Nunan, 1992; Rosa \& Moura, 1997; Moura, 1998; Feitoza et al., 2003). Specimens of this species had not been collected previously, probably because of its cryptic habits.
The Fernando de Noronha Archipelago and Atol das Rocas were probably formed by the Noronha hotspot (Rocha, 2003). Although close (137 km apart), Castro \& Pires (2001) affirm that the Fernando de Noronha Archipelago and Atol das Rocas consist of different coral reef structures and communities, but similar endemic reef fishes are commonly found in the Noronha - Atol insular complex (e.g. Stegastes rocasensis (Emery); Storrsia olsoni Dawson; Starksia multilepis Williams \& Mounts; Elacatinus sp.2 (sensu Moura et al., 2003); Lythrypnus sp.2; Malacoctenus sp.2; Entomacrodus spp. (sensu Moura, 2003); Scartela sp., Ophioblennius sp. (sensu Mendes, 2000); Xyrichthys incandescens Edwards \& Lubbock) (C.L.S. Sampaio, pers. obs.).

Further investigation will probably show the occurrence of Acyrtus pauciradiatus at Atol das Rocas, due to their submerged, shallow ( $<200 \mathrm{~m}$ deep) shelves, which are only about $93 \mathrm{~km}$ apart from Noronha's Archipelago. Furthermore, at about the midway point between the Fernando de Noronha Archipelago and Atol das Rocas lie two seamounts, with relatively flat summits found at depth of 57 and $38 \mathrm{~m}$ respectively, that provide potential intermediate "stepping stones" between their shallow waters faunas (Nunan, 1992; Rocha et al. 2000). Acyrtus artius has been recorded from deep waters, near $33 \mathrm{~m}$ (Johnson \& Greenfield, 1983) suggesting that other members of the genus may reach these depths.

On the other hand, the differentiation of the endemic component of the reef fish faunas of Fernando de Noronha Archipelago and Atol das Rocas is suggested by Nunan (1992) and Rocha (2003) to have occurred rather recently. Brazilian endemic species have been reported to be taxonomically similar to their Caribbean sibling taxa, suggesting a relatively recent origin. The isolation of the two faunas may have occurred probably during the period of maximum terrigenous sediment deposition by the amazing Amazon River estuary and sea-level fluctuations (Floeter \& Gasparini, 2001; Rocha, 2003).

Most clingfishes are small, territorial, benthic demersalspawners or brooders, grow rapidly and probably reach sexual maturity in less than a year (Thresher, 1984). These characteristics have been associated by Floeter \& Gasparini (2001) with most of the Brazilian endemic reef fishes. Williams \& Tyler (2003) presented a discussion about the geographical distribution of the gobiesocid genus Tomicodon, and suggested that the restricted distribution of this genus can be related to the small body size of the included species. Apparently, A. pauciradiatus also has a restricted geographic distribution and appears to be long to one of the smallest oceanic Brazilian reef fish assemblages.

The small number of collected specimens of $A$. panciradiatus together with the suspected restricted distribution of the new species leads to the proposition of a restricted endemic distribution.

Faced with the present limited knowledge about the geographic distribution of the small reef-dwelling fishes, the lack of ecological information and insufficient sampling, especially 
for gobiesocid fishes, it is premature to propose a single meaningful hypothesis of speciation for A. pauciradiatus.

\section{Acknowledgments}

We thank the staff of Águas Claras, Projeto TAMAR and IBAMA from Fernando de Noronha Archipelago, and Universidade de São Paulo (USP) for help with field work, Universidade Federal da Paraíba (UFPB), Universidade Federal do Rio Grande do Norte (UFRN) and Universidade Católica do Salvador (UCSal), ONG Oceânica and Dive Bahia for support. Tatiana Posato, Ierecê Rosa, Paulo Roberto Lopes, Michael Mincarone, João L. Gasparini and, Alfredo Carvalho-Filho for the loan of pertinent literature. Rodrigo Maia-Nogueira (CRMA) and Bruno Bastos (Inst. Baleia Jubarte) for help with photos. Angela Zanata, Darren Wilson and Leo Dutra for improving the English. The comments of anonymous reviewers and Angela Zanata led to improvement of the original version of this paper. CNPq, Brazilian Ministry of Education, provided funding for C. L. S. Sampaio and L. F. Mendes.

\section{Literature Cited}

Böhlke, J. E. \& C. C. G. Chaplin. 1993. Fishes of the Bahamas and Adjacent Tropical Waters. Second Edition. University of Texas Press, Austin. 771p.

Briggs, J. C. 1955. A monograph of the clingfishes (Order Xenopterygii). Stanford Ichthyology Bulletin, 6:1-224.

Castro, C. B. \& D. O. Pires. 2001. Brazilian coral reefs: what we already know and what is still missing. Bulletin of Marine Science, 69(2):357-371.

Eston, V. R., A. E. Migotto, E. C. Oliveira-Filho, S. A. Rodrigues \& J. C. Freitas. 1986. Vertical distribution of benthic marine organisms on rocky coast of the Fernando de Noronha archipelago (Brazil). Boletim do Instituto Oceanográfico de São Paulo, 34:37-53.

Feitoza, B. M., L. A. Rocha, O. J. Luiz-Júnior, S. R. Floeter \& J. L. Gasparini. 2003. Reef fishes of St. Paul's Rocks: new record and notes on biology and zoogeography. Aqua, Journal of Ichthyology and Aquatic Biology, 7(2):61-82.

Floeter, S. R. \& J. L. Gasparini. 2001. Brazilian endemic reef fishes. Coral Reefs, 19:292.

Hutchins, J. B. 2003. Eastern Cleaner-Clingfish Cochleoceps orientalis Hutchins, 1991. http://www.amonline. net.au/ fishes/student/focus/ccchleo.htm (updated April, 2004).

Johnson, R. K. \& D. W. Greenfield. 1983. Clingfishes (Gobiesocidae) from Belize and Honduras, Central America, with a redescription of Bobiesox barbatulus Starks. Northeast Gulf Science, 6(1):33-49.

Lubbock, R. \& A. Edwards. 1981. The fishes of Saint Paul's Rocks. Journal of Fish Biology, 17:283-303.

Maida, M. \& B. P. Ferreira. 1997. Coral reefs of Brazil: an overview. Proceedings 8th International Coral Reef Symposium, Panama, (1):263-274.
Mendes, L. F. 2000. História natural, biologia alimentar, repartição espacial, densidades populacionais e ecomorfologia dos gobióides e blenióides (Perciformes) do Arquipélago de Fernando de Noronha, PE. Unpublished Ph.D. Dissertation, Universidade de São Paulo, São Paulo. 190 p.

Menezes, N. A. 2003. Gobiesocidae. Pp 96 - 97. In: Catálogo das Espécies de Peixes Marinhos do Brasil. N. A. Menezes, P. A. Buckup, J. L. Figueiredo \& R. L. Moura. (Eds). São Paulo, Museu de Zoologia da Universidade de São Paulo, $159 \mathrm{p}$.

Moura, R. L. 1998. Atividade, distribuição e táticas alimentares de uma comunidade de peixes do Atol das Rocas. Unpublished M.Sc. Thesis, Universidade de São Paulo, São Paulo. 108p.

Moura, R. L. 2003. Riqueza de espécies, diversidade e organização de assembléias de peixes em ambientes recifais: um estudo ao longo do gradiente latitudinal da costa brasileira. Unpublished Ph.D. Dissertation, Universidade de São Paulo, São Paulo. 2 vol. 620p.

Moura, R. L., J. L. Figueiredo \& N. A. Menezes. 2003. Gobiidae. Pp 97-100. In: N. A. Menezes, P. A. Buckup, J. L. Figueiredo \& R. L. Moura. (Eds). Catálogo das Espécies de Peixes Marinhos do Brasil Museu de Zoologia da Universidade de São Paulo, São Paulo, 159p.

Nelson, J. S. 1994. Fishes of the world. 3rd Edition, John Wiley $\&$ Sons, New York, 600p.

Nunan, G. W. 1992. Composition, species distribution and zoogeographical affinities of Brazilian reef.-fish fauna. Unpublished Ph.D. Thesis, University of Newcastle upon Tyne, United Kingdom, 520p.

Rocha, L. A. 2003. Patterns of distribution and processes of speciation in Brazilian reef fishes. Journal of Biogeography, 30:1161-1171.

Rocha, L. A., I. L. Rosa \& B. M. Feitoza. 2000. Sponge-dwelling fishes of northeastern Brazil. Environmental Biology of Fishes, 59:453-458.

Rosa, R. S. \& R. L. Moura. 1997. Visual assessment of reef fish community structure in the Atol das Rocas Biological Reserve, off Northeastern Brazil. Proceedings 8th International Coral Reef Symposium, Panama, (1):983-986.

Smith, C. L. 1997. National Audubon Society Field Guide to Tropical Marine Fishes of the Caribbean, Gulf of Mexico, Florida, the Bahamas, and Bermuda. New York, Alfred A. Knopf, Inc. 718p.

Thresher, R. E. 1984. Reproduction in Reef Fishes. T.H.F. Pub. 399p.

Williams, J. T. \& J. C Tyler. 2003. Revision of western Atlantic clingfish of the Tomicodon (Gobiesocidae), with descriptions of five new species. Smithsonian Contributions to Zoology, (621):1-26.

Received July 2004 Accepted November 2004 